\title{
Effect of Joint Mobilization and Kinesio Taping on Pain, Range of Motion, and Knee Function in Patients with Knee Osteoarthritis
}

\author{
Shin-Jun Park, Ju-Hwan Lee \\ Department of Physical Therapy, General Graduate School, Yongin University, Yongin, Korea
}

\begin{abstract}
Purpose: This study was conducted to investigate the effects of joint mobilization and kinesio taping on pain, range of motion and knee function in patients with knee osteoarthritis.

Methods: Thirty subjects were selected and divided into three groups: group 1 was treated with joint mobilization, group 2 was treated with kinesio taping and group 3 was treated with joint mobilization and kinesio taping. Joint mobilization was performed for 20 minutes three times a week for a period of 4 weeks, after which tape was applied for the same period of time and it was not exceeded 24 hours. Pain, range of motion and knee function were then assessed to identify the effectiveness. A visual analog scale (VAS) was used for pain assessment, while active and passive range of motion (AROM, PROM) were assessed using smart phones application, and knee injury and osteoarthritis outcome score (KOOS) was used to assess knee function.

Results: After intervention, the joint mobilization group and kinesio taping group showed significant improvements in VAS, AROM, PROM and KOOS (Symptom, Pain, ADL, QOL), whereas no significant difference was found in sport/recreation. The joint mobilization with kinesio taping group showed significant improvements in all items, and a significant increase was found in AROM and PROM compared to the other two groups.
\end{abstract}

Conclusion: We found that joint mobilization and kinesio taping effectively improved pain, range of motion and knee function in patients with knee osteoarthritis, but that application of joint mobilization with kinesio taping was most effective.

Keywords: Knee osteoarthritis, Mobilization, Kinesio taping.

\section{서 론}

무릎관절염은 관절연골 감소 및 관절 내 생체 역학적 변화를 일으 키는 질환으로 무릎관절 가동범위가 줄어들수록 걸음, 계단오리기, 쪼그려 앉기, 걷기 및 달리기와 점프, 불안정, 통증, 종창과 같은 신체 기능 저하가 나타나 보행 시 무릎의 움직임이 감소하게 되는 결과를 낳는다.1-3 무릎관절염 환자의 기능개선과 통증감소 및 가동범위 증 가를 위한 물리치료로는 운동치료, 물리적 인자치료, 수치료, 관절가 동술이 있는데, 이중 관절가동술은 치료사가 수동적으로 적용하는 방법으로 비교적 안전한 치료방법으로 소개되고 있다. ${ }^{4}$

관절가동술은 동적인 움직임 동안 발생하는 정상적인 구르기-미 끄러짐 움직임과 관절놀기(joint play)를 회복시켜 통증을 감소시키고 기능적 움직임을 증가시키는 효과적인 방법이다. 관절가동술은 수동

Received Sep 13, 2016 Revised Oct 11, 2016 Accepted Oct 17, 2016

Corresponding author Ju-Hwan Lee

E-mail elkael@naver.com
적인 움직임으로 관절수용기를 자극하여 관문조절설의 통증억제기 전의 활성을 통해 관절염환자의 통증을 감소시키고 무릎의 기능을 향상시키며, 관절연골 복원에 긍정적인 영향을 미치는 것으로 보고 되고 있다. ${ }^{5-8}$ 한편 키네시오 테이핑은 탄력테이프를 피부에 부착하 는 방식으로 비교적 경제적이고 안전한 방법이며 다른 치료방법들과 함께 적용이 가능한 이점을 갖는 물리치료 중재 방법이다.9 선행연구 에서 넙다리네갈래근의 테이핑은 관절염 환자의 기계적인 부하를 개 선시키기 위한 방법으로 넙다리네갈래근 긴장도 증가와 함께 고유 수용 감각을 개선시켜 무릎 통증과 기능개선에 긍정적인 효과가 있 는 것으로 보고되었다.10.11

현재까지 뼈관절염 환자에 대한 관절가동술 및 키네시오 테이핑 적용 효과에 대한 연구는 다수 보고되어 왔다. Moss 등', Subramani$\mathrm{an}^{6}$ 은 관절가동술을 무릎에 적용하여 무릎 통증과 무릎 기능이 개

Copylight (C2016 The Korea Society of Physical Therapy

This is an Open Access article distribute under the terms of the Creative Commons Attribution Non-commercial License (Http:// creativecommons.org/license/by-nc/4.0.) which permits unrestricted non-commercial use, distribution, and reproduction in any medium, provided the original work is properly cited. 
선이 되었고, Son 등 ${ }^{12}$, Cho 등 ${ }^{10}$, Anandkumar 등1은 키네시오 테이핑 을 무릎에 적용했을 때 넙다리네갈래근 근력과 무릎의 고유수용감 각 및 관절가동범위 증가, 통증을 감소시키는 결과가 있다고 했다. 또 한 Kanase와 Shanmugam ${ }^{13}$ 의 연구에서는 동결견환자에게 전기치료 (온습포, 초음파), 관절가동술, 키네시오 테이핑을 함께 실시한 군이 전기치료와 관절가동술을 실시한 군보다 통증, 관절가동범위, 기능 장애정도가 유의하게 개선된 것으로 나타났다.

관절가동술은 관절 및 관절주변의 확장을 유지시켜 부동화에 대 한 합병증을 예방하는 효과가 있고, 키네시오 테이핑은 자세를 바르 게 정렬시켜 관절이 바른 상태로 유지하게 해주는 효과가 있는데 선 행연구의 저자는 이 두 가지 치료적 중재에 대한 효과가 합쳐져 관절 가동술만 적용했을 때보다 좋은 결과가 나타난 것이라 하였다.13테이 핑 적용시 나타나는 약화된 근육의 보조, 근육의 기능 회복, 림프 및 혈액 순환을 통한 정체되어 있는 액체 흡수, 신경계 자극을 통한 통 증감소, 피부의 기계적 수용기 촉진을 통한 관절가동범위 증가와 ${ }^{14}$ 관절가동술을 사용하여 관절 수용기를 자극함에 따라 발생하는 근 육의 반사적 촉진과 억제, 신체 내 관절의 위치 인식, 운동감각 증진 과 관문조절설에 의한 신경 생리학적 효과에 의한 유착 및 굳어 있는 조직을 파열하는 기계적 효과는 ${ }^{15}$ 함께 적용될 시 선행연구와 같이 나은 효과를 보인다. 하지만 현재까지 무릎관절염환자에게 관절가 동술 및 키네시오 테이핑을 함께 적용한 연구는 미흡한 실정이다. 비 록 Kumar와 Ganesh ${ }^{16}$ 의 연구에서 메이트랜드 관절가동술과 비탄력 테이핑의 적용에 대한 효과를 비교하였지만 이 연구의 초점은 관절 가동술과 함께 적용되는 테이핑이 무릎뼈 안쪽 혹은 바깥쪽 중 어느 부위에 적용될 때 통증감소에 더욱 효과적인지를 알아보는 것이고 증상개선에 대한 평가방법도 객관적인 평가방법 보다는 통증과 뼈 관절염에 대한 설문지만을 사용했다. 때문에 본 연구에서는 무릎관 절염 환자에게 관절가동술 및 키네시오 테이핑을 동시 적용한 후 통 증과 관절가동범위 및 무릎기능에 관한 효과를 분석하여 향후 무릎 관절염 환자의 치료적 중재에 대한 기초자료를 제공하고자 한다.

\section{연구방법}

\section{1. 연구대상}

이 연구는 서울 소재 B정형외과 병원에 내원 중인 뼈관절염 환자 를 대상으로 2016년 6월 27일부터 7월 29일까지 비동시적으로 진행하 였다. 연구대상자의 선정은 정형외과 의사의 방사선 검사와 이학적 검사를 통해 무릎관절염 진단을 받은 자들 중 선정조건을 만족하는 30 명을 대상으로 하였다. 대상자 선정조건은 관절염 K-L grade (Kellgren-Lawrence grading scale)지수가 2-3에 해당하는 자와 앞쪽, 안쪽, 가쪽에 무릎통증이 있고 시각 상사 척도가 2에서 7 에 해당하는 자
로, ${ }^{17}$ 연구 시작 전에 연구대상자들에게 본 연구와 목적을 충분히 설 명한 서면동의를 받았다. 만약 최근 1 개월 전에 스테로이드 주사를 맞거나 무릎관절 수술 및 관절염 이외에 특별한 질환이 있는 자는 연 구에서 제외하였다. 대상자 선정 후 엑셀(Excel, Microsoft, 미국)을 통 해 임의의 난수를 생성하여 30 명의 연구대상자를 관절가동술을 적용 한 10명(관절가동술군), 키네시오 테이핑을 적용한 10명(테이핑군), 관절가동술과 키네시오 테이핑을 동시적용한 10명(동시적용군)으로 나누어 배치하였다.

\section{2. 측정도구 및 측정방법}

\section{1) 통증측정방법}

무릎관절염 환자의 활동 중에 느끼는 주관적 통증 범위를 측정하 기 위해 시각적 상사 척도(visual analog scale, VAS)를 이용하였다. 10 $\mathrm{cm}$ 의 연속선상의 선에 $0 \mathrm{~cm}$ 은 통증 없음, $10 \mathrm{~cm}$ 은 최악의 통증을 표 시하여 통증강도를 측정하였다. 시각적 상사 척도의 검사-재검사 신 뢰도는 류마토이드 관절염 환자에서 0.97 이 나타났고, ${ }^{18}$ 만성통증에 서 신뢰도는 0.97 로 높았다. ${ }^{19}$

\section{2) 관절가동범위 측정 방법}

무릎관절염 환자의 능동 및 수동 관절가동범위를 측정하기 위해 아이폰6 (A1586, Apple, 미국) Goniometer Pro 어플리케이션(Goniometer Pro 2.7, 5FUF5 Co, 미국)을 사용하여 무릎관절의 굽힘 각도를 측 정하였다(Figure 2,3). 대상자는 바로 누운 자세를 취하였고 무릎을 구부려 각도를 측정하였는데 먼저 넙다리뼈 먼쪽에 스마트폰을 가 로로 세워놓고 넓적다리가 이루는 피부선을 측정하고 뒤이어 정강 뼈 몸쪽에 스마트폰을 가로로 세워두어 정강빼가 이루는 피부선을 측정하였다. 두 선이 이루는 각도를 무릎 굽힘 각도로 설정하였으며 측정 시 엉덩관절이 $90^{\circ}$ 를 넘어가지 않도록 하였다. 이 방법의 측정자 내 신뢰도는 0.81 이고 측정자 간 신뢰도는 0.79 이다. ${ }^{20}$

\section{3) 무릎기능 측정 방법}

무릎관절염 환자의 무릎 기능을 측정하기 위해 무릎 상해와 관절 염 결과 지수(knee injury and osteoarthritis outcome score, KOOS)를 사용하였다.21 KOOS는 증상(7문항), 통증(9문항), 일상생활 기능(17문 항), 운동 및 놀이 활동 기능(5문항), 무릎관절과 관련된 삶의 질(4문 항) 등 5 개의 항목으로 구성되어진다. 문항은 증상이 없으면 0 점이고 4점은 증상이 심하다는 것을 의미하며 점수의 계산은 $\mathrm{KOOS}$ 의 홈페 이지(http://www.koos.nu) 지침에 따라 엑셀을 이용하여 계산하였다. 이 평가도구는 $\mathrm{Seo}^{22}$ 가 한국 실정에 맞게 번역 및 표준화 하였고 검 사-재검사 신뢰도는 증상 및 경직성이 0.79 , 통증이 0.89 , 일상생활이 0.75 운동 및 놀이기능이 0.77 , 삶의 질이 0.79 이다. ${ }^{22}$ 


\section{3. 연구방법}

중재는 주 3 회씩 4 주간 실시되었고 중재전 각 군의 대상자는 일반 적인 물리치료를 받았다(온습포, 간섭전류치료 15 분, 초음파 5 분). 테 이핑 부착시간은 하루에 한 번 24시간"을 넘기지 않도록 하였고 관절 가동술은 15 분간 무릎에 시행하였다. ${ }^{8}$ 동시적용군의 경우 키네시오 테이핑을 부착한 상태에서 무릎 관절가동술을 적용하였다. 통증과 관절가동범위 및 무릎기능에 대한 측정은 첫 중재 시작 전, 중재 4 주 후에 평가하였다.

\section{1) 무릎 관절가동술}

무릎뼈 Kaltenborn식 관절가동술로서 연구대상자는 바로 누운 자 세에서 무릎아래에 모래주머니를 받치고 편안한 위치로 관절을 놓 은 다음 연구자는 치료하려는 넙다리를 잡고 고정하였다. 연구자는 무릎뼈(patella)를 잡고 안쪽(medial)방향 등급II-III을 적용하였다. 같 은 방법으로 가쪽(lateral) 방향과 먼쪽(distal)방향으로 미끄러뜨림을 적용하였다. 당김(traction)적용은 연구대상자가 엎드린 자세에서 관 절을 편안한 위치에 놓은 다음 연구자는 넓적다리 뒤쪽을 잡고 고정 한 후 정강뼈를 먼쪽(distal)으로 당겨 시행하였다. 관절가동술은 최 소 30 초 동안 번갈아가며 시행하였고 중재시간은 15 분간 반복하여 진행하였다.

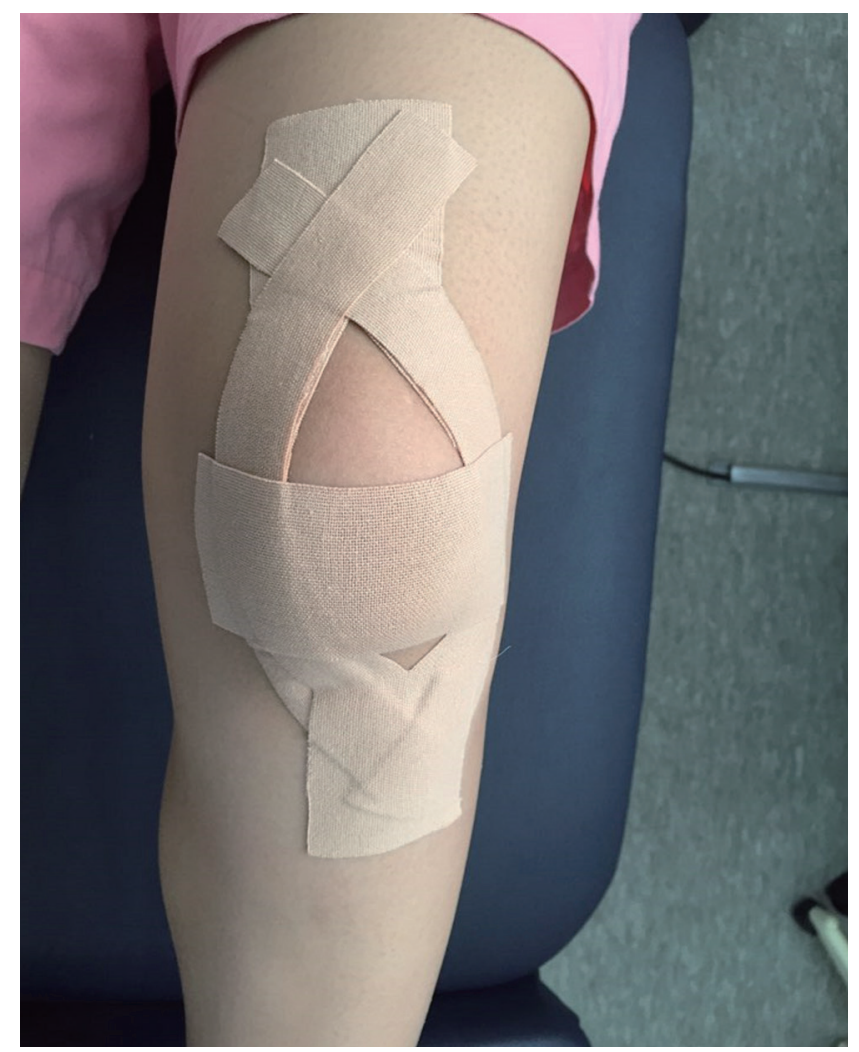

Figure 1. The picture of taping on quadriceps muscle.

\section{2) 키네시오 테이핑}

본 연구에 사용한 테이프는 폭 $5 \mathrm{~cm}$ 의 탄력 테이프(elastic tape) (Benefact, Nippon Sigmax Co. Ltd, 일본)로 먼저 각 연구대상자들의 다 리에 맞는 테이프 길이를 측정한 다음 $\mathrm{Y}$ 모양 테이프 2 개와 $\mathrm{I}$ 모양 테이 프 1개를 다리에 적용하였다(Figure 1). 첫 번째 $\mathrm{Y}$ 모양 테이프는 25\% 신장력을 적용하여 무릎을 최대한 굽힘한 상태에서 무릎뼈 안쪽과 가쪽에 감싸주어 부착하였고 나머지는 위앞엉덩뼈가시 방향을 향 하여 신장 없이 부착하였다. 두 번째 Y 모양 테이프는 무릎이 $90^{\circ}$ 굽 힘된 상태에서 정강뼈거친면에 먼저 부착하였고 나머지 두 갈래를 무릎뼈 안쪽과 가쪽에 감싸주어 적용하였다. 세 번째 I모양 테이프는 무릎을 30 도 굽힘한 상태에서 $75 \%$ 신장력을 적용하여 부착하였고 양쪽 끝에서는 신장을 가하지 않았다. ${ }^{23}$ 테이프 적용 시 가렵거나 피 부문제가 나타날 경우 제거하도록 교육하였지만 증상을 호소한 자 는 없었다.

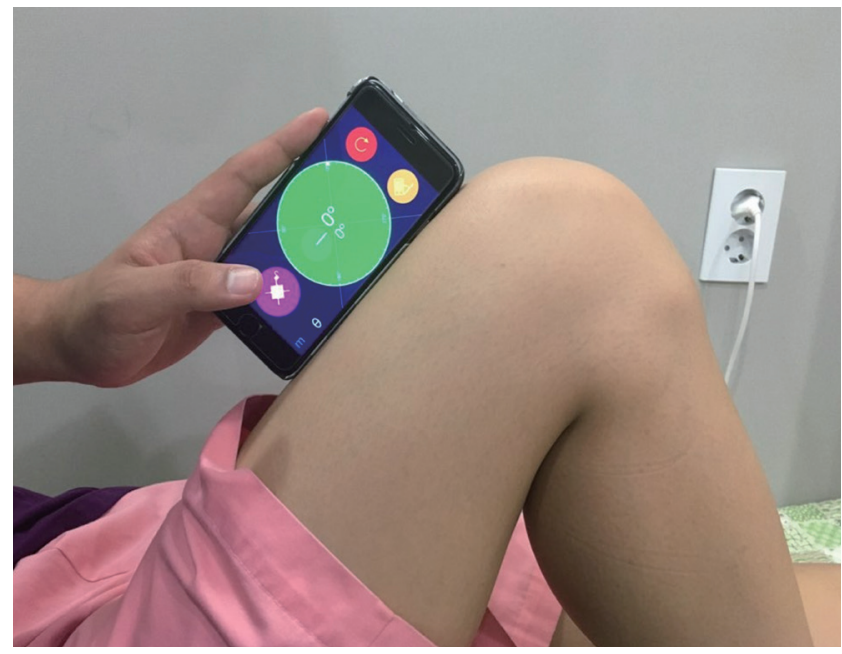

Figure 2. Measurement of the distal femur.

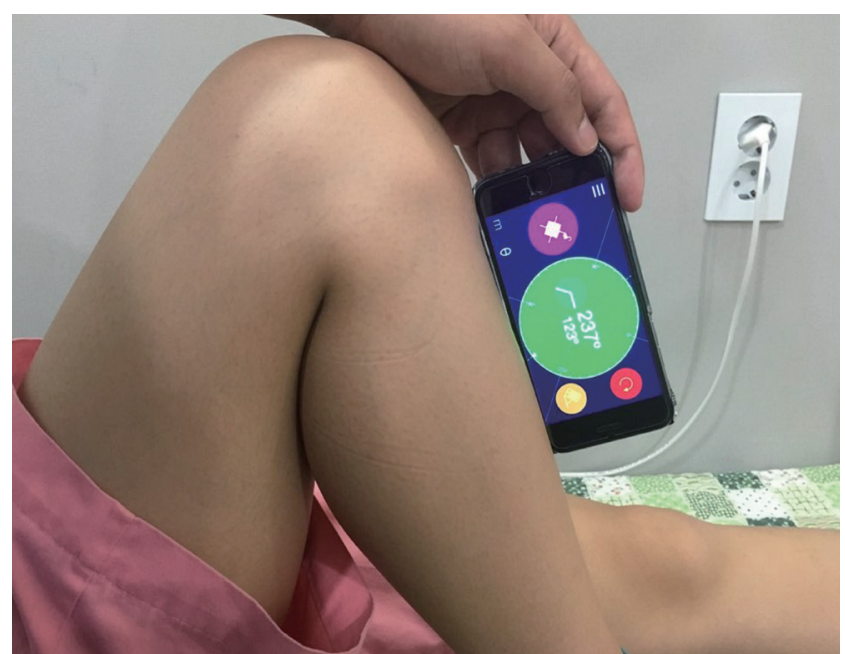

Figure 3. Measurement of the proximal tibia. 


\section{4. 자료분석}

본 연구에서 수집된 모든 데이터는 통계처리프로그램 SPSS WIJN (ver. 21)을 사용하여 분석하였다. 각 연구군의 정규성 검정은 Kolmogorov-Smirnov 검정을 통해 정규성 검정을 확인하였고, 연구군들의 중 재 전과 중재 후 통증, 관절가동범위, 무릎기능의 차이는 대응표본 $\mathrm{t}$ 검정(paired t-test), 연구군 간 중재 전. 후 차이는 일원배치 분산분석 (one way ANOVA)을 사용하여 분석하였다. 사후검정으로 최소유의 차검정(least significant difference test, LSD)을 사용하였고, 모든 통계 학적 유의수준으로 $\alpha=0.05$ 로 하였다.

\section{결 과}

\section{1. 연구대상자의 일반적인 특성}

본 연구대상자의 일반적 특성은 다음과 같다(Table 1). 관절가동술 군의 성별은 남성 2 명, 여성 8 명, 침범부위는 왼쪽 4 명, 오른쪽 4 명, 양 쪽 2 명, 평균 나이는 $60.80 \pm 6.80$ 세, 평균 키는 $160.30 \pm 6.02 \mathrm{~cm}$, 평균 몸 무게는 $61.50 \pm 9.74 \mathrm{~kg}$ 이었다. 키네시오 테이핑군의 성별은 남성 3 명, 여성 7 명, 침범부위는 왼쪽 3 명, 오른쪽 5 명, 양쪽 2 명, 평균 나이는 $66.30 \pm 11.40$ 세, 평균 키는 $164.70 \pm 9.04 \mathrm{~cm}$, 평균 몸무게는 $68.10 \pm 10.51$ $\mathrm{kg}$ 이었다. 동시적용군의 성별은 남성 1 명, 여성 9명, 침범부위는 왼쪽 4
명, 오른쪽 4 명, 양쪽 2 명, 평균 나이는 $65.70 \pm 7.17$ 세, 평균 키는 159.80 $\pm 4.57 \mathrm{~cm}$, 평균 몸무게는 $65.60 \pm 13.61 \mathrm{~kg}$ 이었다. 세 군간 일반적인 특 성의 유의한차이는 없었다 $(\mathrm{p}>0.05)$.

\section{2. 중재 전·후 통증 비교}

중재 전·후 세 군 모두 통증정도의 유의한 감소가 있었다 $(\mathrm{p}<0.01)$ (Table 2). 관절가동술군은 $5.00 \pm 1.41$ 에서 중재후 $2.10 \pm 1.10$ 으로 유의 하게 감소하였고, 테이핑군은 $4.70 \pm 0.82$ 에서 $2.20 \pm 0.78$ 로 유의하게 감소하였다. 동시적용군은 $4.40 \pm 1.17$ 에서 $1.60 \pm 0.52$ 로 유의하게 감소 하였다. 세 군간 중재 전. 후 통증에선 유의한 차이는 없었다 $(\mathrm{p}>0.05)$.

\section{3. 중재 전·후 관절가동범위 비교}

세 군 모두 중재 전. 후 능동 및 수동 무릎관절 굽힘 가동범위의 유 의한 증가가 있었다 $(\mathrm{p}<0.01)$ (Table 3$)$. 관절가동술군의 능동 무릎관 절 굽힘 가동범위는 $120.90 \pm 6.98$ 에서 중재 후 $127.80 \pm 6.37$ 로 유의하 게 증가하였고 테이핑군은 $119.80 \pm 7.13$ 에서 $126.50 \pm 7.12$ 로 유의하게 증가하였다. 동시적용군의 능동무릎관절 굽힘 가동범위는 $119.60 \pm$ 6.00에서 중재 후 $128.40 \pm 6.33$ 으로 유의하게 증가하였다. 또한 관절가 동술군, 키네시오 테이핑군, 동시적용군의 중재 후 수동 무릎관절 굽 힘 가동범위도 각각 $125.00 \pm 6.91$ 에서 $133.00 \pm 6.14$ 로 $123.60 \pm 6.54$ 에서

Table 1. General characteristics of subjects (Mean \pm SD)

\begin{tabular}{lcccc}
\hline & KJMG & Taping & Mobilization with taping \\
$(\mathrm{n}=10)$ & $(\mathrm{n}=10)$ & $1 / 9$ & $\mathrm{p}$ \\
Gender (male/female) & $2 / 8$ & $3 / 7$ & $4 / 4 / 2$ & 0.535 \\
Involvement (left/right/both) & $4 / 4 / 2$ & $3 / 5 / 2$ & $65.70 \pm 7.17$ & 0.987 \\
Age (year) & $66.80 \pm 6.30$ & $66.30 \pm 11.40$ & $159.80 \pm 4.57$ & 0.960 \\
Height (cm) & $160.30 \pm 6.02$ & $164.70 \pm 9.04$ & $65.60 \pm 13.61$ & 0.228 \\
Weight (kg) & $61.50 \pm 9.74$ & $68.10 \pm 10.51$ & 0.437 & \\
\hline
\end{tabular}

KJMG: knee joint mobilization group.

Table 2. Comparison of pain rating scale in three groups (Mean \pm SD)

\begin{tabular}{|c|c|c|c|c|c|c|}
\hline & \multicolumn{2}{|c|}{ Mobilization } & \multicolumn{2}{|c|}{ Taping } & \multicolumn{2}{|c|}{ Mobilization with taping } \\
\hline & Before & After & Before & After & Before & After \\
\hline VAS (cm) & $5.00 \pm 1.41$ & $2.10 \pm 1.10^{+}$ & $4.70 \pm 0.82$ & $2.20 \pm 0.78^{+}$ & $4.40 \pm 1.17$ & $1.60 \pm 0.52^{+}$ \\
\hline
\end{tabular}

VAS: visual analog scale.

${ }^{+} p<0.01$.

Table 3. Comparison of range of motion in three groups (Mean \pm SD)

\begin{tabular}{|c|c|c|c|c|c|c|}
\hline & \multicolumn{2}{|c|}{ Mobilization } & \multicolumn{2}{|c|}{ Taping } & \multicolumn{2}{|c|}{ Mobilization with taping } \\
\hline & Before & After & Before & After & Before & After \\
\hline AROM & $120.90 \pm 6.98$ & $127.80 \pm 6.37^{+}$ & $119.80 \pm 7.13$ & $126.50 \pm 7.12^{+}$ & $119.60 \pm 6.00$ & $128.40 \pm 6.33^{+, \neq, \$}$ \\
\hline PROM & $125.00 \pm 6.91$ & $133.00 \pm 6.14^{+}$ & $123.60 \pm 6.54$ & $130.70 \pm 5.76^{+}$ & $123.40 \pm 5.99$ & $132.60 \pm 6.59^{+,+, \$}$ \\
\hline
\end{tabular}

AROM: active range of motion, PROM: passive range of motion.

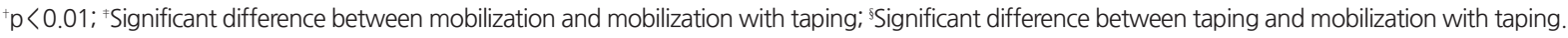


Table 4. Comparison of KOOS in three groups (Mean \pm SD)

\begin{tabular}{|c|c|c|c|c|c|c|}
\hline & \multicolumn{2}{|c|}{ Mobilization } & \multicolumn{2}{|c|}{ Taping } & \multicolumn{2}{|c|}{ Mobilization with taping } \\
\hline & Before & After & Before & After & Before & After \\
\hline Symptom & $44.29 \pm 11.19$ & $52.50 \pm 15.71^{*}$ & $48.21 \pm 16.43$ & $56.07 \pm 15.62^{+}$ & $44.64 \pm 15.54$ & $56.43 \pm 12.35^{+}$ \\
\hline Pain & $47.22 \pm 12.96$ & $55.00 \pm 11.54^{\star}$ & $46.39 \pm 13.86$ & $55.28 \pm 13.25^{\star}$ & $46.94 \pm 16.22$ & $58.06 \pm 15.90^{+}$ \\
\hline ALD & $51.76 \pm 10.53$ & $58.53 \pm 12.32^{*}$ & $49.26 \pm 12.92$ & $57.21 \pm 15.82^{*}$ & $49.71 \pm 14.74$ & $57.35 \pm 14.87^{+}$ \\
\hline Sport/Re & $27.50 \pm 7.17$ & $33.50 \pm 11.07$ & $26.00 \pm 13.29$ & $33.00 \pm 19.03$ & $29.00 \pm 19.41$ & $37.00 \pm 18.74^{+}$ \\
\hline QOL & $38.13 \pm 9.52$ & $45.63 \pm 8.36+$ & $35.00 \pm 8.44$ & $42.50 \pm 10.94^{*}$ & $40.00 \pm 12.22$ & $46.88 \pm 12.24^{+}$ \\
\hline
\end{tabular}

$A D L$ : activities of daily living, Sport/Re: sport/recreation, QOL: quality of life. ${ }^{*} \mathrm{p}<0.05 ;{ }^{\mathrm{p}} \mathrm{p}<0.01$

$130.70 \pm 5.76$ 으로 $123.40 \pm 5.99$ 에서 $132.60 \pm 6.59$ 로 유의하게 증가하였 다. 중재 전. 후 관절가동범위의 그룹 간 비교에서 유의한 차이가 나 타나 최소유의차 검정으로 분석한 결과 동시적용군이 나머지 두 군 보다 능동 및 수동 관절가동범위에서 유의하게 개선되었음을 알 수 있었다 $(\mathrm{p}<0.05)$.

\section{4. 중재 전·후 무릎기능 비교}

관절가동술군 및 키네시오 테이핑군에선 KOOS의 증상, 통증, 일상 생활 기능, 무릎관절과 관련된 삶의 질 항목이 중재 후 유의하게 증가 한 것으로 나타났고 $(\mathrm{p}<0.05)$, 동시적용군은 $\operatorname{KOOS}$ 의 증상 $(\mathrm{p}<0.01)$, 통 증 $(\mathrm{p}<0.01)$, 일상생활 기능 $(\mathrm{p}<0.01)$, 운동 및 놀이활동 기능 $(\mathrm{p}<0.01)$, 무릎관절과 관련된 삶의 질 항목이 유의하게 증가한 것으로 나타났 다 $(\mathrm{p}<0.01)$ 중재 전·후 무릎기능에 대한 그룹간 비교에선 유의한 차 이는 나타나지 않았다( $\mathrm{p}>0.05)($ Table 4).

\section{고 찰}

무릎관절염 환자에게 적용되는 관절가동술과 키네시오 테이핑은 통증과 관절가동범위 증가 무릎과 관련된 신체기능 개선을 시키는 효과적인 물리치료 중재 방법이다. ${ }^{4}$ 관절가동술과 키네시오 테이핑 의 적용은 근력운동과 같은 운동치료보다 근피로의 위험이 적기 때 문에 현재까지 다양한 질병을 지닌 환자를 대상으로한 연구가 진행 되었고 그 결과로 관절가동술과 키네시오 테이핑이 각각 적용됐을 때 보단 일반적인 운동치료 혹은 근력운동과 함께 적용하였을때의 결과가 단일적용보다 더욱 효과적이라는 연구결과에도 불구하고 정 작 관절가동술과 키네시오 테이핑을 함께 적용한 연구는 국내·외에 서 미흡한 실정이기에 본 연구에서는 무릎관절염 환자에게 관절가 동술과 테이핑을 동시적용하여 통증, 관절가동범위, 무릎기능에 대 한 효과를 단일적용시의 경우와 비교하고자 하였다. 본 연구의 관절 가동술군 및 키네시오 테이핑군에선 중재 전. 후 각 그룹내 통증, 관 절가동범위, 무릎기능에 관한 척도인 $\mathrm{KOOS}$ 척도의 항목 중 증상, 통 증, 일상생활기능, 무릎관절과 관련된 삶의 질 항목이 유의하게 개선
된 것으로 나타났다.

관절가동술을 통한 관절 공간의 미끄러짐 및 당김은 관절 수용기 (joint receptor)를 통해 통증수용기를 억제하고 고유수용감각을 촉진 하며 유착조직의 분리와 같은 기계적 효과를 증진시킨다. ${ }^{15,24}$ Subra$\operatorname{manian}^{6}$ 의 연구에선 정강 넙다리 관절의 당김(traction)을 무릎관절 염환자에게 2주간 적용하였을 때 통증과 무릎기능, 무릎 굽힘 관절 가동범위가 개선되었고, 전통적인 물리치료와 함께 무릎뼈의 모든 방향에서 미끄러짐, 정강뼈의 앞-뒤방향 미끄러짐을 적용한 연구에 서는 전통적인 물리치료만 받은 대조군보다 관절가동술을 추가로 적용한 군에서 통증의 감소를 보였다. ${ }^{25}$ 때문에 본 연구의 관절가동 술군에서도 선행연구와 유사한 결과가 나타난 것으로 사료된다.

무릎관절염 환자에게 적용한 테이핑 연구에서는 테이핑 적용 전 후 무릎기능 증가와, 통증감소에 유의한 차이를 보였고 이것은 단파 투열기보다 효과적이었다. ${ }^{17} \operatorname{Son}^{12}$ 은 무릎과 종아리에 테이핑을 적용 하여 통증 및 일어나 걸어가기 시간의 감소, 무릎 굽힘 관절가동범위 의 증가를 보였고, $\mathrm{Lee}^{26}$ 는 무릎에 테이핑과 함께 4 주간 전통적인 물 리치료(conservative treatment)를 병행하여 실시하여 한국판 western ontario macmaster (WOMAC)점수 감소와 통증의 감소, 무릎의 관절 가동범위에 증가를 보였다. $\mathrm{Akbaş}^{27}$ 의 연구에서 테이핑과 근력운동은 근력운동만 적용한 군에 비해 근육의 수동 신장성에서 증가를 보였 고 이러한 이유로는 테이핑을 통한 피부 기계수용기(cutaneous mechanoreceptor) 활성을 촉진시켜 물렁조직의 유연성과 생리적 변화를 일 으켜 발생한다고 하여 본 연구의 결과와 유사하였다. 테이핑은 피부 의 압박과 자극을 통해 관절의 안정성을 증가시키고, ${ }^{9}$ 부착 부위 관 절의 주변근육을 개선 시키게 되어 비정상적 움직임이 정상화시킨 다. ${ }^{28}$ 때문에 본 연구에서도 선행연구와 유사한 결과가 나타난 것으 로 사료된다.

Saavedra-Hernández ${ }^{29}$ 은 만성 목통증이 있는 환자를 대상으로 도 수교정(manipulation)과 테이핑의 중재 효과를 비교하였는데 중재 전 후 목의 굽힘, 폄, 가쪽 굽힘 증가와 통증 영역에서 감소를 보였으나 군간 차이를 보이지 않아 군간 비슷한 효과를 보고하였다. 본 연구의 결과에서도 관절가동술군과 키네시오 테이핑군의 중재 전. 후 통증 
과 관절가동범위가 증가하였으나 두 군간 유의한 차이가 없었다. 이 러한 이유로는 4 주간의 중재 기간 동안 관절가동술의 경우 하루에 15 분간 짧게 실시하여 효과를 보인 반면 최대 부착 시간이 24 시간인 테이핑은 피부 긴장을 통한 근막의 기능 회복을 오랜 기간 지속하기 때문에 ${ }^{30}$ 테이핑이 관절가동술과 비슷한 효과를 보인 것으로 사료된 다.

본 연구의 동시적용군에선중재 전. 후 통증, 관절가동범위 및 $\mathrm{KOOS}$ 의 모든 항목이 유의하게 개선되었고, 특히 나머지 두 군 보다 능동 및 수동 관절가동범위에서 유의한 증가가 나타났다.

관절가동술은 관절 주변에 존재하는 기계적 수용기를 활성화 시 켜 근육의 반사적 반응(reflexive responses)을 변화시키고 통증으로 인한 연축(spasm)을 경감 시키므로 관절의 가동범위를 증진 시킬 수 있다..$^{5}$ 또한 테이핑 요법은 혈류의 흐름과 림프의 순환을 증진하여 재흡수를 촉진시키고 피부의 기계적 수용기를 활성을 통해 가동범 위를 증진을 도와준다. ${ }^{14,27}$ 그러므로 본 연구에서 적용한 관절가동술 과 키네시오 테이핑 동시 적용은 관절과 피부에 존재하는 수용기를 모두 활성화 시키므로 능동 및 수동 관절가동범위에 더욱 증가가 나 타난 것으로 사료된다.

또한 동시적용군에서는 다른 군과는 달리 KOOS의 운동 및 놀이 기능 항목에서 유의한 증가가 있었다. KOOS의 운동 및 놀이기능 항 목에는 쪼그려 앉을 때, 달릴 때, 뛰어 오를 때, 다친 무릎으로 회전하 거나 비틀 때, 무릎 꼻음에 관한 항목을 포함하고 있다. 세 군간 비교 에서 동시적용군의 무릎관절 굽힘가동범위는 관절가동술과 키네시 오 테이핑을 단일적용한 다른 군에 비해 유의하게 큰 증가폭을 보였 다. 때문에 무릎굽힘능력이 요구되는 운동 및 놀이기능 항목에서도 동시적용군의 유의한 증가가 나타난 것으로 사료된다.

$\mathrm{Lee}^{31}$ 는 뼈관절염 대상으로 관절가동술과 일반적 물리치료의 효 과를 비교한 결과 관절가동술과 일반적 물리치료를 함께 적용한 군 에서 통증의 감소와 폄 관절가동범위가 증가한 반면 온습포, 경피신 경전기자극기, 초음파 치료를 이용한 일반적 물리치료군에서는 통증 의 감소를 보였으나 무릎 폄 관절가동범위에서 유의한 차이가 없었 다. 본 연구에서 적용한 일반적 물리치료는 통증 감소를 목적으로 온 습포, 중주파, 초음파가 동일하게 적용되었다. 따라서 가동범위 증가 보다 통증 감소에 영향을 더 주는 일반적 물리치료는 세 군의 통증의 문턱값을 증가시킨 반면 관절가동범위에선 영향을 보이지 않아 가 동범위에서 차이가 나타난 것으로 사료된다.

지금까지 결과를 통해 다음과 같이 해석할 수 있다. 뼈관절염 환자 에게 관절가동범위 증진에 효과가 있는 관절가동술을 단독 작용하 는 것 보다 일반적인 운동치료나 근력운동과 함께 적용하는 것이 신 체기능 및 관절가동범위 회복에 더욱 효과적이다. ${ }^{32,33}$ 하지만 근력운 동이나 일반적인 운동치료는 치료사의 지도가 필요하므로 비교적 단
순한 적용방법으로 치료시간이 짧고 부착시간이 긴 키네시오 테이핑 요법 ${ }^{30}$ 과 관절가동술을 함께 적용한다면 치료시간 이후 일상생활에 서도 뼈관절염 환자의 관절가동범위 회복에 도움이 될 것이라 사료된 다. 본 연구에서는 4 주간의 짧은 중재를 통해 장기간 적용 했을 때의 치료 효과에 대해 알 수 없는 제한점이 있다. 또한 대상자의 수가 적었 고 대상자의 심리적 상태를 완전히 배제하지 못하였다. 따라서 향후 연구에서는 심리적 평가와 함께 더 많은 대상자와 장기간 중재에 따 른 예후 변화를 확인한다면 더욱 구체적인 차이를 알 수 있을 것이라 사료된다.

\section{참고문헌}

1. Felson DT. Osteoarthritis of the knee. N Engl J Med. 2006;354(8):841-8.

2. Park SK, Park RJ, Kim TY. The effect of functional impairment on limitation of flexion and extension in patients with knee osteoarthritis. J Kor Phys Ther. 2001;13(3):643-51.

3. Lee IH, Kwon GH, Park SY. Biomechanical properties of the anterior walker dependent gait of patients with knee osteoarthritis. J Kor Phys Ther. 2013;25(5):239-45.

4. Cho SW, Kang YK. Recent studies about sonservative treatment of osteoarthritis in knee joint. Kor J Ori Med Physiol Pathol. 2010;24(6):111728.

5. Moss P, Sluka K, Wright A. The initial effects of knee joint mobilization on osteoarthritic hyperalgesia. Man Thera. 2007;12(2):109-18.

6. Subramanian IL. Effectiveness of manual traction of tibio-femoral joint in the functional outcome in knee joint osteoarthritis. Indian Journal of Physical Therapy. 2014;2(1):56-61.

7. Kim SH, Nam KW, Seo DY. Effects of swimming exercise and joint mobilization on HSP 70 levels in osteoarthritic rats. J KorPhys Ther. 2014; 26(6):418-24.

8. Kaltenborn F, Evjenth O. Manual mobilizations of the joints: the kaltenborn method of joint examination and treatment. Vol. 1: the extremities. 6th ed. Universitetsgaten, Norli. 2002:105-294.

9. Kim SM. The effects of taping on musculoskeletal system pain and dysfunction. Journal of Coaching Development. 2007;9(3):81-93.

10. Cho HY, Kim EH, Kim J et al. Kinesio taping improves pain, range of motion, and proprioception in older patients with knee osteoarthritis: a randomized controlled trial. Am J Phys Med Rehabil. 2015;94(3):192200.

11. Anandkumar S, Sudarshan S, Nagpal P. Efficacy of kinesio taping on isokinetic quadriceps torque in knee osteoarthritis: a double blinded randomized controlled study. Physiother Theory Pract. 2014;30(6):375-83.

12. Son GS, Lee M H, Lee CR el al. The effects of kinesio taping on the pain and functional improvement in patients with degenerative arthritis. Korean Journal of Sport Biomechanics. 2008;18(1):45-52.

13. Kanase SB, Shanmugam S. Effect of kinesiotaping with Maitland mobilization and Maitland mobilization in management of frozen shoulder. IJSR. 2014;3(9):1817-21.

14. Yoshida A, Kahanov L. The effect of kinesio taping on lower trunk range of motions. Research in sports medicine. 2007;15(2):103-112.

15. Kim SY. Effects of joint mobilization techniques on the joint receptors. 
Physical Therapy Korea. 1996;3(2):95-105.

16. Kumar A, Ganesh BR. Combined effectiveness of Mmaitland's mobilization and patellar taping in patellofemoral osteoarthritis: a randomized clinical trial. Indian Journal of Physiotherapy and Occupational Therapy-An International Journal. 2011;5(1):14-7.

17. Haryadi R, Subadi I, Husna N. Effectiveness of kinesio taping compared with short wave diathermy on pain perception and functional status in knee osteoarthritis patients. Folia Medica Indonesiana 2014;50(4):23944.

18. Ferraz MB, Quaresma MR, Aquino LR et al. Reliability of pain scales in the assessment of literate and illiterate patients with rheumatoid arthritis. J Rheumatol. 1990;17(8):1022-4.

19. Price DD, McGrath PA, Rafii A et al. The validation of visual analogue scales as ratio scale measures for chronic and experimental pain. Pain. 1983;17(1):45-56.

20. Jenny JY. Measurement of the knee flexion angle with a smartphone-application is precise and accurate. J Arthroplasty. 2013;28(5):784-7.

21. Roos EM, Roos HP, Lohmander LS et al. Knee injury and osteoarthritis outcome score (KOOS)-development of a self-administered outcome measure. J Orthop Sports Phys Ther. 1983;28(2):88-96.

22. Seo SS, Chung KC, Kim YB. Assessment of validity, reliability and responsiveness of Korean knee injury and osteoarthritis outcome score (KOOS) for the knee injury. J Korean Orthop Assoc. 2006;41(3):441-53.

23. Kocyigit F, Turkmen MB, Acar M et al. Kinesio taping or sham taping in knee osteoarthritis? a randomized, double-blind, sham-controlled trial. Complement Ther Clin Pract. 2015;21(4):262-7.

24. Park JW. Basic concepts of joint motion in peripheral joint mobilization. J Kor Phys Ther. 1994;6(1):155-61.

25. LYN K. Effects of passive joint mobilization on patients with knee osteo- arthritis. Sains Malaysiana. 2011;40(12):1461-5.

26. Lee K, Yi CW, Lee S. The effects of kinesiology taping therapy on degenerative knee arthritis patients' pain, function, and joint range of motion. J Phys Ther Sci. 2016;28(1):63.

27. Akbaş E, Atay AO, Yüksel, I. The effects of additional kinesio taping over exercise in the treatment of patellofemoral pain syndrome. acta orthopaedica et traumatologica turcica. 2010; 45(5):335-41.

28. Son GS, Lee MH, Lee SY et al. The effects of kinesio taping on the muscle activities of vastus lateralis and medialis in patients with degenerative arthritis. J Kor Phys Ther. 2007;19(1):45-55.

29. Saavedra-Hernández M, Castro-Sánchez AM, Arroyo-Morales M et al. Short-term effects of kinesio taping versus cervical thrust manipulation in patients with mechanical neck pain: a randomized clinical trial. journal of orthopaedic \& sports physical therapy, 2012;42(8):724-30.

30. Kaya DO, Baltaci G, Toprak U et al. The clinical and sonographic effects of kinesiotaping and exercise in comparison with manual therapy and exercise for patients with subacromial impingement syndrome: a preliminary trial. Journal of manipulative and physiological therapeutics. 2014;37(6):422-32.

31. Lee NY, Kwon CS, Song SH. The effect of manual joint mobilization on pain, rom, body function and balance in patients with knee osteoarthritis. Korean Society of Physical Medicine, 2015;10(4):91-9.

32. Park EK, Ahn WH, Lee DS. The effect of exercise program on range of motion, pain relief for patient with the knee osteoarthritis. Journal of Sport and Leisure Studies. 2011; 45(2):853-61.

33. Jansen MJ, Viechtbauer W, Lenssen, AF et al. Strength training alone, exercise therapy alone, and exercise therapy with passive manual mobilization each reduce pain and disability in people with knee osteoarthritis: a systematic review. Journal of physiotherapy. 2011;57(1):11-20. 